Journal of Social Research and Behavioral Sciences

Original Article Received/Accepted Dates 05.11.2021/21.12.2021

DOI: 10.52096/jsrbs.7.14.15

\section{Sosyal Araştırmalar ve Davranış Bilimleri Dergisi \\ ISSN:2149-178X}

Volume: 7 Issue: 14 Year: 2021

\title{
Koronavirüs Salgını Sürecinde Öğretmen Yaşantıları
}

\section{Salih YILMAZ}

Dr., Millî Eğitim Bakanlığı

ylmz_salih@hotmail.com

ORCID: 0000-0002-5890-0699

\author{
Prof. Dr. Necdet KONAN \\ İnönü Üniversitesi \\ Eğitim Fakültesi \\ necdet.konan@inonu.edu.tr
}

ORCID: 0000-0001-6444-9745

\section{Özet}

Bu araştırmanın temel amacı, koronavirüs salgını sürecinde öğretmen yaşantılarını belirlemektir. Böylelikle uzaktan öğretim sürecinde öğretmenleri en çok nelerin etkilediği, öğretmenlerin nelere özlem duyduğu ve salgın sonrası yapmak istedikleri belirlenmeye çalışılmıştır. Araştırmanın amacını gerçekleştirmek için olgubilim deseninde nitel bir araştırma gerçekleştirilmiştir. Araştırmanın çalışma grubunu, 2020-2021 öğretim yılında Malatya ilindeki ilkokul, ortaokul ve liselerde görev yapan toplam 53 öğretmen oluşturmaktadır. Araştırma verileri, araştırmacılar tarafından geliştirilen yarı yapılandırılmış görüşme formu aracılığıyla toplanmış ve içerik analiziyle çözümlenmiştir. Araştırma sonunda koronavirüs salgını sürecinde öğretmenleri en çok etkileyen konuların; Öğrenci Velilerinin Yaşadı̆̆ı Ekonomik Zorluklar, Öğrencilerden Uzak 


\section{Koronavirüs Salgını Sürecinde Öğretmen Yaşantıları}

Kalma, Öğretmenlerin Çabası/Gayreti, Öğrencilerin Gayreti/Çabası, Hastalı̆̆a Yakalanma, Verilen Kayıplar, Sosyalleşememe, Online Derslere Ilgisizlik, Derslere Yetersiz Katıllım, Uygulamalı Dersler, Diğer - Olumlu ve Olumsuz Yönler ile ilgili olduğu görülmüştür. Diğer yandan öğretmenlerin bu süreçte nelerin özlemini çektiği ve koronavirüs sonrasında yapmayı istediği şeyler, Sosyal İlişkiler, Maskesiz Yaşam, Özgürce Gezme ve Sınıf Ortamı-Yüz Yüze Eğitim ile ilgili olmuştur.

Anahtar Kelimeler: Öğretmen, koronavirüs salgını, uzaktan öğretim

\section{Teacher Experiences During the Coronavirus Outbreak}

\section{Summary}

The main purpose of this research is to determine the experiences of teachers during the coronavirus epidemic. Thus, it has been tried to determine what affects teachers most in the distance education process, what the teachers miss and what they want to do after the epidemic. In order to realize the purpose of the research, a qualitative research was carried out in the phenomenology design. The study group of the research consists of 53 teachers working in primary, secondary and high schools in Malatya in the 2020-2021 academic year. Research data were collected through a semi-structured interview form developed by the researchers and analyzed by content analysis. At the end of the research, the issues that most affect teachers during the coronavirus epidemic process; It has been seen that it is related to the economic difficulties experienced by the parents of the students, being away from the students, the efforts of the teachers, the effort of the students, the disease, the losses, the inability to socialize, the indifference to the online lessons, the insufficient participation in the lessons, the practical lessons, the other - positive and negative aspects. On the other hand, what the teachers longed for in this process and what they wanted to do after the coronavirus were related to Social Relations, Maskless Life, Free Traveling and Classroom Environment-Face to Face Education.

Keywords: Teacher, coronavirus epidemic, distance education 


\section{Giriş}

Koronavirüs salgını, tüm ülkeleri etkisi altına almış ve ülkelerin eğitim öğretim süreçlerinde aksamalara yol açmıştır. Ülkeler, yaşanan bu aksamaların önüne uzaktan öğretim ile geçme çabası içine girmiştir. Salgının başlarında ve belirli bir süre, Türkiye’de de sayısı milyonları bulan öğrenci ve öğretmen evlerinde kalarak teknolojik araçlar yardımıyla öğrenme ve öğretme süreçlerini gerçekleştirmeye çalışmıştır. Uzaktan öğretim süreci, zaman zaman yüz yüze eğitimle beraber yürütülmüş, günümüzde aşıya erişim ve aşılama oranının artmasıyla uzaktan öğretimin ağırlığı, yüz yüze eğitime doğru geçmeye başlamıştır. Okul bileşenlerinin yaşantıları ise bu süreçten çeşitli şekillerde etkilenmiştir.

Koronavirüs (COVID-19) salgını, eğitim sistemleri için küresel düzeyde ciddi endişeler oluşturmaktadır. COVID-19'u kontrol altına alma çabaları, dünya çapında 100'den fazla ülkede okulların plansız olarak kapanmasına neden olmuş, okullarının kapanması ile bir milyardan fazla öğrenci okul dışında kalmıştır (Onyema vd., 2020). Türkiye, Çin, İtalya, ABD ve İngiltere gibi birçok ülke, pandeminin eğitim üzerindeki etkisini en aza indirmek için yüz yüze eğitime ara vererek uzaktan eğitime geçmiş (Hebebci, Bertiz ve Alan, 2020). Eğitim kurumlarının en önde gelen çalışanları oldukları için öğretmenler, çevrimiçi öğretimin başarısı için de vazgeçilmez bir konuma sahip olmuştur (Joshi, Vinay ve Bhaskar, 2020). Nitekim okul sistemleri yalnızca teknik birleşimlerden meydana gelmezler, insani duygular ve ilişkiler, öğrenme girişiminin merkezinde yer alır. Pandemi sırasında öğretmenleri dinlemeye ve yaşamlarının ve çalışmalarının karmaşıklığını anlamaya devam etmek, kısa vadede etkili bir yanıt oluşturmak ve uzun vadede daha sağlam, esnek sistemler oluşturmak için çok önemli olacaktır (Reich, vd., 2020).

Öğretmenler, COVID-19 salgınının bir sonucu olarak önemli stres yaşamışlardır. Dolayısıyla öğretmenlerin iyi oluşlarını desteklemek, öğretmenler, öğrenciler ve bir bütün olarak eğitim sistemi için önemli olumsuz sonuçları önlemek için kritik öneme sahiptir (Baker vd., 2021). Okulların açılarak etkili bir şekilde işlerliğinin sürdürebilmesi etkili planlama, öğretmenlerin deneyimlerini anlama ve karşılaştıkları zorlukları ele almak ile sağlanabilir. Bu sebeple koronavirüs salgını boyunca uzatılan okul kapanışları sırasında eğitimcilerin uygulamaları ve mesleki deneyimlerinin derinden anlaşılması önem taşımaktadır (Reich, vd., 2020). Bu sürecin yürütülmesinde büyük payı sahip olan öğretmenlerin görüşlerinin alınması, sonraki süreçlerin 


\section{Koronavirüs Salgını Sürecinde Öğretmen Yaşantıları}

daha etkili bir şekilde deneyimlenmesine olanak sağlayacağından alanyazına katkı getirebilir (Kazu, Bahçeci ve Kurtoğlu Yalçın, 2021).

$\mathrm{Bu}$ araştırmanın temel amacı, koronavirüs salgını sürecinde öğretmen yaşantılarını ortaya çıkarmaktır. Böylelikle uzaktan öğretim sürecinde öğretmenleri en çok nelerin etkilediği, öğretmenlerin nelere özlem duyduğu ve salgın sonrası yapmak istedikleri belirlenmeye çalışılmıştır.

\section{Yöntem}

Araştırmanın amacını gerçekleştirmek için olgubilim deseninde nitel bir araştırma gerçekleştirilmiştir. Bu tür araştırmalarda farkında olunan ancak hakkında ayrıntılı bir anlayışın olmadığı olgulara odaklanılmaktadır (Yıldırım ve Şimşek, 2011).

Araştırmanın çalışma grubunu, 2020-2021 öğretim yılında Malatya ilindeki ilkokul, ortaokul ve liselerde görev yapan toplam 53 öğretmen oluşturmaktadır. Katılımcılara ait demografik bilgiler Tablo 1'de sunulmuştur.

Tablo 1. Katılımc1lara ait Demografik Bilgiler

\begin{tabular}{|c|c|c|c|c|}
\hline $\begin{array}{c}\text { Katılımeı } \\
\text { Kodu }\end{array}$ & Cinsiyet & Branşınız & Okul Türü & Kidem \\
\hline Ö1 & Kadın & Din Kültürü ve Ahlak Bilgisi & Lise & 16 \\
\hline Ö2 & Kadın & Sınıf Öğretmeni & İlkokul & 21 \\
\hline Ö3 & Kadın & Sınıf Öğretmeni & İlkokul & 8 \\
\hline Ö4 & Erkek & Sınıf Öğretmeni & İlkokul & 12 \\
\hline Ö5 & Kadın & Fen Bilimleri & Ortaokul & 16 \\
\hline Ö6 & Kadın & Okul Öncesi & İlkokul & 13 \\
\hline Ö7 & Kadın & Sınıf Öğretmeni & İlkokul & 21 \\
\hline Ö8 & Kadın & Sosyal Bilgiler & Ortaokul & 8 \\
\hline
\end{tabular}




\begin{tabular}{|c|c|c|c|c|}
\hline Ö9 & Kadın & Din Kültürü ve Ahlak Bilgisi & Lise & 5 \\
\hline Ö10 & Kadın & Türkçe & Ortaokul & 11 \\
\hline Ö11 & Kadın & Beden Eğitimi & Ortaokul & 23 \\
\hline Ö12 & Erkek & Okul Öncesi & Okul öncesi & 2 \\
\hline Ö13 & Kadın & Sınıf Öğretmeni & İlkokul & 13 \\
\hline Ö14 & Kadın & Din Kültürü ve Ahlak Bilgisi & Ortaokul & 7 \\
\hline Ö15 & Erkek & Biyoloji & Lise & 12 \\
\hline Ö16 & Erkek & Sınıf Öğretmeni & İlkokul & 25 \\
\hline Ö17 & Erkek & Türkçe & Ortaokul & 15 \\
\hline Ö18 & Erkek & Sinıf Ögretmeni & İlkokul & 10 \\
\hline Ö19 & Kadın & Matematik & Lise & 25 \\
\hline Ö20 & Kadın & Fen Bilimleri & Ortaokul & 7 \\
\hline Ö21 & Erkek & Bilgisayar & Ortaokul & 1 \\
\hline Ö22 & Kadın & Türk Dili ve Edebiyat1 & Lise & 4 \\
\hline Ö23 & Erkek & Elektrik Elektronik & Lise & 23 \\
\hline Ö24 & Kadın & Elektronik & Lise & 8 \\
\hline Ö25 & Kadın & Beden Eğitimi & Lise & 24 \\
\hline Ö26 & Kadın & İlköğretim Matematik & Ortaokul & 6 \\
\hline Ö27 & Erkek & Elektrik & Lise & 28 \\
\hline Ö28 & Kadın & Beden Eğitimi & Ortaokul & 9 \\
\hline Ö29 & Kadın & Okul Öncesi & Okul öncesi & 6 \\
\hline Ö30 & Kadın & Bilişim & Ortaokul & 20 \\
\hline Ö31 & Kadın & Türk Dili ve Edebiyat1 & Lise & 4 \\
\hline
\end{tabular}


Koronavirüs Salgını Sürecinde Ö̆̆retmen Yaşantıları

\begin{tabular}{|c|c|c|c|c|}
\hline Ö32 & Erkek & Fotoğraf & Lise & 1 \\
\hline Ö33 & Kadın & Sinıf Öğretmenliği & İlkokul & 5 \\
\hline Ö34 & Kadın & Sinıf Öğretmenliği & İlkokul & 1 \\
\hline Ö35 & Erkek & Yenilenebilir Enerji & Lise & 23 \\
\hline Ö36 & Kadın & Sinıf Öğretmeni & İlkokul & 18 \\
\hline Ö37 & Erkek & Matematik & Ortaokul & 1 \\
\hline Ö38 & Kadın & Sınıf Öğretmeni & İlkokul & 5 \\
\hline Ö39 & Erkek & İngilizce & Ortaokul & 1 \\
\hline Ö40 & Kadın & Okul Öncesi & İlkokul & 1 \\
\hline Ö41 & Erkek & Sosyal Bilgiler & Ortaokul & 12 \\
\hline Ö42 & Kadın & İngilizce & Ortaokul & 16 \\
\hline Ö43 & Kadın & Sosyal Bilgiler & Ortaokul & 3 \\
\hline Ö44 & Kadın & Sinıf Öğretmeni & İlkokul & 2 \\
\hline Ö45 & Kadın & İngilizce & İlkokul & 1 \\
\hline Ö46 & Kadin & Türkçe & Ortaokul & 3 \\
\hline Ö47 & Kadın & Fen Bilgisi & Ortaokul & 5 \\
\hline Ö48 & Kadın & Sinıf Öğretmeni & İlkokul & 8 \\
\hline Ö49 & Erkek & Din Kültürü ve Ahlak Bilgisi & Ortaokul & 5 \\
\hline Ö50 & Kadın & Din Kültürü ve Ahlak Bilgisi & Lise & 13 \\
\hline Ö51 & Erkek & İngilizce & Lise & 7 \\
\hline Ö52 & Kadın & Okul Öncesi & Okul öncesi & 5 \\
\hline Ö53 & Kadın & Sınıf Öğretmeni & İlkokul & 5 \\
\hline
\end{tabular}


Araştırma verileri, araştırmacılar tarafından geliştirilen yarı yapılandırılmış görüşme formu aracılığıyla çevrimiçi toplanmış ve içerik analiziyle çözümlenmiştir. Katılımcılar Ö1, Ö2, Ö3... şeklinde kodlanmış ve katılımcıların ifadeleri ilgili temalar altında doğrudan paylaşılmıştır.

\section{Bulgular}

Araştırmanın amacı doğrultusunda ilk olarak oluşturulan “Uzaktan ögretim sürecinde sizi en çok etkileyen (olumlu ve/veya olumsuz) yaşantınızı / anınızı / gözleminizi / tanıklı̆̆ınızı paylaşır mısınız?" sorusuna yanıt bulmak amacıyla katılımcılardan elde edilen veriler analiz edilmiştir. Analizler sonunda, Öğrenci Velilerinin Yaşadı̆̆ Ekonomik Zorluklar (f=16), Öğrencilerden Uzak Kalma (f=6), Öğretmenlerin Çabası/Gayreti $(f=5)$, Öğrencilerin Gayreti/Çabası $(f=4)$, Hastalı̆̆a Yakalanma $(f=4)$, Verilen Kaylplar $(f=3)$, Sosyalleşememe $(f=3)$, Online Derslere Ilgisizlik $(f=3)$, Derslere Yetersiz Katılım ( $f=2)$, Uygulamalı Dersler $(f=2)$, Diğer - Olumlu ve Olumsuz Yönler $(f=9)$ şeklinde 11 temaya ulaşılmıştır. Koronavürüs sürecinde öğretmenleri etkileyen konulara ilşikin tema ve katılımcı kodları Tablo 2'de paylaşılmıştır.

Tablo 2. Öğretmenleri Etkileyen Konular

\begin{tabular}{ll}
\hline Temalar & Katılımcı Kodları \\
\hline Öğrenci Velilerinin Yaşadığ1 Ekonomik & Ö8, Ö10, Ö14, Ö16, Ö17, Ö20, Ö21, Ö23, \\
Zorluklar & Ö27, Ö29, Ö30, Ö31, Ö35, Ö36, Ö45, Ö49 \\
\hline Öğrencilerden Uzak Kalma & Ö9, Ö18, Ö19, Ö38, Ö48, Ö53 \\
\hline Öğretmenlerin Çabası/Gayreti & Ö13, Ö32, Ö33, Ö34, Ö37 \\
\hline Öğrencilerin Gayreti/Çabas1 & Ö4, Ö8, Ö15, Ö51 \\
\hline Hastalığa Yakalanma & Ö5, Ö11, Ö13, Ö39 \\
\hline Verilen Kayıplar & Ö9, Ö40, Ö46 \\
\hline Sosyalleşememe & Ö1, Ö5, Ö42
\end{tabular}


Koronavirüs Salgını Sürecinde Ö̆̆retmen Yaşantıları

\begin{tabular}{ll}
\hline Online Derslere İlgisizlik & Ö15, Ö22, Ö47 \\
\hline Derslere Yetersiz Katılım & Ö43, Ö44 \\
\hline Uygulamal1 Dersler & Ö24, Ö28 \\
\hline Diğer - Olumlu Yönler & Ö6, Ö7, Ö25, Ö26, Ö50 \\
\hline Diğer - Olumsuz Yönler & Ö2, Ö3, Ö12, Ö52 \\
\hline
\end{tabular}

Öğrenci Velilerinin Yaşadığı Ekonomik Zorluklar Teması altında toplanan katılımcı görüşlerinden bazıları şu şekildedir:

"Ailesinin tuşlu telefonu olduğu için okul gruplarına dâhil edemediğimiz ögrencilerden uzaktan eğitime katılımını istemek” Ö8

"Bir öğrencim öğretmenin diğer derse giremeyeceğim internetimiz bitti dedi, bu beni çok üzmüştü” Ö10

"Öğrencimin bir tanesinin dışarda komşusunun internetinin çekmesi için dışarda dinlemiş katılmıştı. Hava soğuktu ekranını açınca fark ettim ve çok üzüldüm” Ö14 "En önemli olay iki öğrencinin nöbetleşerek derse girmesiydi, bir tane telefon ile giriyorlardı. Üzücüydü keşke iki aletleri olsaydl sonra MEB tablet verdi." Ö16

"Telefonum çalmıştı. Açtım öğrencim ăgllyor. Derslere katılmadı̆̆ından ve ailesinin durumundan bahsetti. Katılmak istediğini fakat kardeş saylsı fazla olduğundan katılmasının imkânsız olduğundan söz etti. Başarmak isteyen ögrencilerimden biri. Fakat bazı konulardaki eksiklik yetersizlik maalesef onu da beni de çok üzdü. Ve bu konuda bizim de bir şeyler yapamamamız, benim en çok üzüldüğüm konulardan oldu. Çalı̧̧an azim gösteren öğrencilerimizin maddi yetersizliklerden kaybetmek..." Ö17

Öğrencilerden Uzak Kalma Teması altında toplanan katılımcı görüşlerinden bazıları şu şekildedir: 
“Öğrencilerimin sik sık araması, mesaj gönderip okulu beni özlediklerini söylemesi beni mutlu etti. Çeşitli sorunlart olan, okuldan uzak öğrencimin bile mesaj gönderip güzel düşüncelerini iletmesi bana çok iyi geldi” Ö9

"Öğrencilerin derslerden ve okuldan uzun süre uzaklaşması kötü etkiledi” Ö18 "Okula gidememek ve ögrrencisiz eğitimin anlamın yitirdiğini görmek üzücü oldu” $\ddot{O} 19$

Öğretmenlerin Çabası/Gayreti Teması altında toplanan katılımcı görüşlerinden bazıları şu şekildedir:

"Hem 30 saat canlı ders, 2 çocuk, hem yüksek lisans yapinca bu süreçte çok yorulduğumu ve yıprandığımı inkâr edemem" Ö13

"Evden ders vermek teknoloji vb. açılarından zorlad, dijital bir yorgunluk oluştu" $\ddot{O} 32$

"Bir gün mutfak camına dönük şekilde ders yaparken camın baya buğulandığını gördüm. Neyse dikkat etmedim, geçer dedim, baktım geçmiyor, aksine çoğallyor. Nedenini çok sonra fark ettim ki ocakta su kaynıyor, hatta bitmek üzere...”ö33

Öğrencilerin Gayreti/Çabası Teması altında toplanan katılımcı görüşlerinden bazıları şu şekildedir:

“Öğrencilerin dersler için istekli olması, gayret etmesi” Ö4

"ilkokul, ortaokul ve lise de ögrencisi olan bir ailede derslere sırayla katıldıklarını söylediklerinde etkilenmiştim." Ö8

“Her derse katıllp bir şeyler ögrenmek isteyen öğrenciler. " Ö15

"Bazı ögrencilerin imkânsızlıklara rağmen bilgiye ulaşmaya çalı̧̧ma gayreti beni etkiledi." Ö51

Hastalığa Yakalanma Teması altında toplanan katılımcı görüşlerinden bazıları şu şekildedir: "Eşimin covid sürecini çok sıkıntıll geçirmişs olması, beni epey yıprattı" Ö5 


\section{Koronavirüs Salgını Sürecinde Öğretmen Yaşantıları}

“Uzaktan eğitim sürecinde ailece Covid-19'a yakalandık. Hastalık süreci sıkıntılı geçti” Ö11

“Ailece covid 19 hastallk sürecimiz çok zor geçti” Ö13

“Ailemin hastalı̆̆a yakalanması” Ö39

Verilen Kayıplar Teması altında toplanan katılımcı görüşlerinden bazıları şu şekildedir:

“ت̈züldüğ̈̈m olaya gelince, birkaç öğrencim bu süreçte anne ve babasını kaybetti. Bugün bir ögrencimin babası defnedildi. Gerçekten bunlara çok üzüldüm. Ölüm gerçeği kendini hep hissettiriyor" Ö9

"Uzaktan ögretim sürecinde beni en çok izlediğim bir haber etkilemişti. Anne baba ögretmen olan bir çiftin canlı ders sırasında çocuklarını üst kattaki komşusuna bırakmışlardl. Canlı ders sırasında çiftin küçük çocukları balkondan düşüp ölmüştü. Bu beni çok üzmüştü” Ö40

"Eylül ayında sınıf rehber öğretmeni olduğum sınıftan bir öğrencimin annesi, dedesi ve halası covid sebebiyle vefat etti. Öğrencimin fiziki olarak yanında olamamak beni çok üzdü. Sadece telefonla teselli edebildim bunun da ne kadar etkili olduğu tartışılır. ” Ö46

Sosyalleşememe Teması altında toplanan katılımcı görüşlerinden bazıları şu şekildedir:

“Gurbette yaşayan biri olarak ailem ile bir araya gelebildiğim sinırlı saatlerde onlara sarllamamak beni çok etkilemişti” Ö1

"Insanlardaki sosyalleşmeme, buhrana dönmeye başladı. Toplumsal kaygllar yaşlyorum. " Ö5

"Insanların birbirine yabancılaşması, evlere kapanmamı, sosyal ilişkilerimizin sekteye ŭgramast. " Ö42 
Online Derslere İlgisizlik Teması altında toplanan katılımcı görüşlerinden bazıları şu şekildedir: “Olumsuz örnek ise isteyerek derse hiç katılmayanlar.” Ö15 “Öğrenciler derse girmiş gibi görünüyor sistemi açıp gidiyorlar, biz boş boş ders anlatıyoruz." Ö22

“Öğrencilerin sınıf ortamından daha çok dersi kaynatması.” Ö47

Derslere Yetersiz Katılım Teması altında toplanan katılımcı görüşlerinden bazıları şu şekildedir: "Derslere katılamayan ya da katılmayan öğrencilerin hiçbir ĕgitim almadan evde vaktini boş geçirmesi beni olumsuz yönde etkiledi." Ö43

“27 tane öğrencim var sadece üç tanesi uzaktan öğretime katıllyor. Bu üç ögrencim bazen katılıp bazen katılmıyor. Konularda ilerleyemiyoruz. Kendimi boşa kürek çekiyormuş gibi hissediyorum. " Ö44

Uygulamalı Dersler Teması altında toplanan katılımcı görüşlerinden bazıları şu şekildedir:

“Öğrenci katılımının kısıtlı olması, branşım gereği uygulamalı derslerimi yapamamış olmanın eksikliğini hissettim” Ö28

“Uzaktan derslere çok az ögrencinin katılması. Uygulamaları yapamamak” Ö24

Diğer - Olumlu Yönler Teması altında toplanan katılımcı görüşlerinden bazıları şu şekildedir:

“Okul öncesi ögretmeni olarak veliler vermiş olduğumuz eğitimin kalitesini ve niteliğini anladılar, yaptı̆̆ımız işin zorluklarını bizimle beraber paylaşmış oldular. " Ö6

“Dönem sonunda ailelerin sürecin çok güzel gittiğini ve çocukların her şeyi ögrendiklerini en başta bu sürecin nasıl olacă̆ı konusunda tereddütte olduklarını ama ĕgitim sonunda çocukların başarılarının çok güzel olduğunu belirtmeleri beni mutlu etti. " Ö7 


\section{Koronavirüs Salgını Sürecinde Öğretmen Yaşantıları}

"Yüz yüze yapılan ĕgitimin ne kadar etkili ve verimli olduğunu fark ettirdi bu süreç.” $\quad$ Ö25

“Milletçe bir ve beraberdik.” Ö26

"Not verirken haksıllk yapacă̆ımı düşündüm. Herhangi bir ölçüt olmadı̆̆ından tüm ögrencilerime en yüksek puanı verdim. " Ö50

Diğer - Olumsuz Yönler Teması altında toplanan katılımcı görüşlerinden bazıları şu şekildedir:

“Bazı ögrrencilerimizin özellikle kalabalık ortamlarda sobalı evlerde ders dinlemeye çalışmaları, ailedekilere konuşmamasını sürekli söylemesi” Ö2

"Ders ortamında çocukların sürekli öğretmenim beni görebiliyor musun, orası senin evin mi gibi sorularla ders işlemeye çalışmak” $\quad \ddot{O} 3$

"İnsanların salgının tehlikesini gerçek anlamda hâlâ idrak edememiş olması ve tedbirlere riayet edilmemesi konusu beni gerçekten şaşırtıyor.” Ö12

"Çocukların düzenleri bozuldu, hırçınlaştılar, tablet, telefon, pc bağımlılıkları arttı. Onlarca whatsapp grubuna üye yaptılar. İş yaşamı. Ev yaşamı birbirine karıştı” Ö52

Araştırmada ikinci ve son olarak "En çok neyin özlemini çekiyorsunuz? Bu salgın süreci sona erdiğinde ilk yapmak istediğiniz şey nedir?" sorularına yanıt aranmıştır. Bu doğrultuda öğretmenlerin en çok özlem duyduğu konular ve yapmak istedikleri, Sosyal İlişkiler (f=25), Maskesiz Yaşam (f=13), Özgürce Gezme (f=10), Sınıf Ortamı-Yüz. Yüze Ĕ̌itim $(f=6)$ şeklinde 4 tema altında toplanmıştır. Koronavürüs süreci sebebiyle öğretmenlerin özlem duydukları ve süreçten sonra yapmak istediklerine ilşikin tema ve katılımcı kodları Tablo 3 'te paylaşılmıştır. 
Tablo 3. Öğretmenlerin Özlem Duydukları ve Yapmak İstedikleri

\begin{tabular}{ll}
\hline Temalar & \multicolumn{1}{c}{ Katılımcı Kodları } \\
\hline & Ö1, Ö5, Ö8, Ö9, Ö11, Ö12, Ö13, Ö17, \\
Sosyal İlişkiler & Ö19, Ö20, Ö23, Ö24, Ö25, Ö28, Ö31, \\
& Ö32, Ö35, Ö39, Ö41, Ö42, Ö43, Ö45, \\
& Ö47, Ö48, Ö52 \\
\hline Maskesiz Yaşam & Ö7, Ö4, Ö14, Ö34, Ö10, Ö18, Ö22, Ö23, \\
& Ö36, Ö38, Ö40, Ö46, Ö49 \\
\hline \multirow{2}{*}{ Özgürce Gezme } & Ö2, Ö3, Ö6, Ö16, Ö21, Ö29, Ö30, Ö37, \\
\hline Sınıf Ortam1-Yüz Yüze Eğitim & Ö44, Ö51 \\
\hline
\end{tabular}

Sosyal İlişkiler Teması altında toplanan katılımcı görüşlerinden bazıları şu şekildedir:

"Yakınlarımla özgürce görüşmek, sohbet etmek, rahatça birbirimize gelip gitmek." $\ddot{0} 9$

“Eski günleri özlüyorum dışarıda oturmak arkadaş sohbetleri” Ö17

"İ̧̧ içe oturup rahat hareket etmek ve isteğim arkadaş akraba ziyaretleri" Ö19

"Yüz yüze sohbet etmeyi, sarllmayl, annemin babamin elini öpmeyi özledim. Kapımı çalan hal hatır soranların varllğını istiyorum." Ö20

"Arkadaşlarımızla oturup korkusuzca sabahlara kadar oyun oynayıp sohbet etmek" $0 \ddot{2} 3$

"Eskisi gibi korku kaygl duymadan sevdiklerimle özgürce vakit geçirmek” Ö24

“Çay ocağı veya kafeteryada arkadaşlarımla çay içmeyi özledim.” Ö35

"Sevdiğimiz insanlarla samimi ortamlarl” Ö45

"Sevdiklerime sarllmak, onlarla birlikte yüz yüze vakit geçirmeyi özledim. Çocuklarla sınıfta etkinlik yapmayı özledim." Ö48 


\section{Koronavirüs Salgını Sürecinde Öğretmen Yaşantıları}

Maskesiz Yaşam Teması altında toplanan katılımcı görüşlerinden bazıları şu şekildedir:

"En çok maskesiz gezmeyi ve gönül rahatlı̆̆ılla ailemle arkadaşlarımla kucaklaşmayı özlüyorum." Ö4

“Yürümek, rahat rahat nefes almak, maskeyle çok zor” Ö14

“Maskesiz bir hayatın özlemini çekiyorum.” Ö38

“Maskesiz özgürce gezebilmeyi ve seyahat edebilmeyi özledim.” Ö40

“Normal hayata, maskesiz hayata tekrar dönebilmek” Ö49

Özgürce Gezme Teması altında toplanan katılımcı görüşlerinden bazıları şu şekildedir:

“Rahat rahat yürümenin, sarllmanın, kalabalı davetlere katılmak” Ö3

“Tatile çıkmanın ve özgürce dışarıda dolaşmanın özlemini çekiyorum” Ö6

“Özgürce hafta sonları balı̆̆a çıkmak ve eşimle doğa yürüyüşü yapmak” Ö21

"İçimde korku olmadan sokağa çıkıp gezmek” Ö37

Sınıf Ortamı-Yüz Yüze Eğitim Teması altında toplanan katılımcı görüşlerinden bazıları şu şekildedir:

“Yüz yüze eğitim” Ö27

"Rahatça ders yapabildiğim, öğrencilerimle mesafeye dikkat etmeden geçirdiğim zamanlarl özlüyorum. ” Ö33

“Öğrencilerime sarılmanın, sınıfımda ders anlatmanın özlemini çekiyorum. “ Ö53 


\section{Sonuç ve Öneriler}

$\mathrm{Bu}$ araştırmada koronavirüs sürecinde öğretmen yaşantılarının belirlenmesi amaçlanmıştır. Araştırma sonunda koronavirüs salgını sürecinde öğretmenleri en çok etkileyen konuların Öğrenci Velilerinin Yaşadığı Ekonomik Zorluklar, Öğrencilerden Uzak Kalma, Öğretmenlerin Çabası/Gayreti, Öğrencilerin Gayreti/Çabası, Hastalığa Yakalanma, Verilen Kayıplar, Sosyalleşememe, Online Derslere İlgisizlik, Derslere Yetersiz Katılım, Uygulamalı Dersler ve Diğer - Olumlu ve Olumsuz Yönler ile ilgili olduğu görülmüştür. Diğer yandan öğretmenlerin bu süreçte nelerin özlemini çektiği ve koronavirüs sonrasında yapmayı istediği şeyler, Sosyal İlişkiler, Maskesiz Yaşam, Özgürce Gezme ve Sınıf Ortamı-Yüz Yüze Eğitim ile ilgili olmuştur.

Benzer bulgulara çeşitli araştırmalarda da rastlanmıştır. Örneğin Joshi, Vinay ve Bhaskar (2020) tarafından yapılan araştırmada, koronavirüs salgını ile başlayan çevrimiçi öğretim ve değerlendirme süreçlerinde öğretmenler, dış dikkat dağıtıcılar ve ailelerin neden olduğu kesintiler, bütçe ve donanım yetersizlikleri, teknik zorluklar, olumsuz tutum ve montivasyon eksikliği gibi konularda yaşanan sorunlardan etkilenmiştir. Bir başka çalışmada (Yolcu, 2020), soru sorma imkânının yetersizliği, hoca ve arkadaşlarla olan iletişim eksikliği, ev ortamındaki dikkat dağınıklığı ve uygulamalı dersler için uzaktan eğitimin uygunsuzluğu ifade edilmiştir. Benzer bir araştırmada (Konan ve Gür, 2021), fen bilimleri öğretmenleri, öğrencilerin teknolojik altyap1 yetersizliği, ders katılımlarının az olması ve yaparak yaşayarak öğrenmenin azlığı konularını dile getirmiştir.

Koronavirüs sürecinde öğretmenlerin dile getirdiği sorunların çeşitli araştırmalarda; teknolojik malzeme ve imkân yetersizliği, internet altyapı ve bağlantı sorunu yaşanması, canlı derslere öğrencilerin katılımının düşük olması, öğrenciye ulaşamama ve öğretimin beklenen şekilde ve kalitede olamaması şeklinde ifade edilmiş̧tir (Konan ve Koçer, 2021). Ayrıca öğretmenlerin bu süreçte yaşadıkları en büyük korkuların hastalığa yakalanma, bulaştırma, kalıcı hasara maruz kalma ve ölüm olduğu; salgın sona erdiğinde katılımcıların en çok yapmak istedikleri şeyin ise sevdikleriyle zaman geçirmek ve yüz yüze eğitim olduğu belirlenmiştir (Konan ve Kıymaz, 2021; Konan ve Nacar, 2021).

Uzaktan eğitim; belirli zaman ve mekândan bağımsız, teknolojik materyaller vasıtasıyla katılımcılar ile birlikte eğitim öğretimin gerçekleştirilmesi süreci olup hem uygulayıcı hem de 


\section{Koronavirüs Salgını Sürecinde Öğretmen Yaşantıları}

kullanıcı için teknolojik anlamda materyal imkânının var olması dikkat edilmesi gereken unsurlardan biri olarak gösterilmektedir (Moçoşoğlu ve Kaya, 2020). Uzaktan eğitime ilişkin yapılan bir metafor çalışmasında, katılımcı öğretmenlerin daha çok olumsuz metaforlar ürettiği, bu sürecin istenilen düzeyde verimli geçmediğini düşündükleri; öğrencilerin bu süreci yeterince ciddiye almamaları ve teknik alt yapı eksikliği sorununun bu sürecin verimsiz geçmesine sebep olduğu şekliden görüşler ortaya çıkmıştır (Kazu, Bahçeci ve Kurtoğlu Yalçın, 2021).

Bir çalışmada (Li, vd., 2020), COVID-19 salgını sırasında öğretmenler arasında kaygı durumunun bozulduğu anlaşılmıştır. Benzer bir araştırmada (Baker, vd., 2021), COVID-19 salgını öğretmenler üzerinde önemli beklentiler oluşturduğu; bu süreçte daha fazla stres yaşayan öğretmenlerin daha kötü zihinsel sağlı durumu yaşadığını ve bununla başa çıkmada zorlandığı dile getirilmiştir. Ayrıca pandemi sırasında öğretimin en zorlu yönleri, bağlantı eksikliği ve çevrimiçi öğretim zorlukları olarak ifade edilmiş, iş arkadaşlarından ve yöneticilerden gelen destek ise öğretmenlere en çok yardımcı olan durumlar olarak görülmüştür. Aynı zamanda, öğretmenlerden bu süreçle zorluklarla başa çıkmada güç kazandığını ifade edenler olmuştur. Nitekim Hebebci, Bertiz ve Alan (2020) tarafından yapılan araştırmaya katılan öğretmenler, uzaktan eğitim sürecinin olumlu yönlerini vurgulayarak, eğitimin sürdürülmesinin önemine dikkat çekmiştir.

ABD'de yapılan araştırmada (Reich, vd., 2020), devlet, sözleşmeli ve özel okullarda, farklı sınıf seviyelerinde ve farklı ders alanlarında 40 öğretmenle görüşme yapılmıştır. Görüşmelerden üç ana tema ortaya çıkmıştır: 1) Öğrenci Motivasyonu: Öğretmenler, öğrencilerini bilgisayar ekranı aracılığıyla motive etmek için mücadele etmişlerdir; 2) Mesleki Kayıp ve Tükenmişlik: Öğretmenler, tanıdık öğretim araçlarını kaybettikçe, kendi yeterliklerine ve mesleki kimliklerine ilişkin temel bir duyguyu kaybetme hissi yaşamıştı;; 3) Artan Eşitsizlikler: Öğretmenler, öğrencilerinin hayatlarını şekillendiren toplumsal eşitsizliklerin dramatik bir şekilde yoğunlaşmasına tanık oldukça, bu kayıp duygusu daha da derinleşmiştir. Diğer yandan yaş, cinsiyet, öğrenim düzeyi, okul konumu, endişe düzeyi, kayg1, korku düzeyi gibi faktörler koronavirüs sürecinde öğretmenleri etkileyen unsurlar olarak ifade edilmektedir (Li, vd., 2020).

Bir araştırma merkezi tarafindan öğretmenler ve okul bölgesi yöneticileri üzerine yapılan anket sonuçlarına göre, COVID-19 salgınının bir sonucu olarak Amerika'nın K-12 eğitim sisteminin uzaktan öğrenmeye geçişte okullar arasında büyük farklılıklar göze çarpmıştır. Bunların en önemlileri arasında, ülkenin en fakir ve en zengin okulları arasındaki temel teknolojiye erişim ve 
canlı uzaktan eğitim kapsamında yaşanan eksiklikler ve oturum açmadığı veya iletişim kurmadığını bildiren öğrencilerin sayılarının fazlalığı olduğu dile getirilmiştir (Herold, 2020). Bu kapsamda eşitlik, ilişki kurmaya odaklanma, öğrenci motivasyonu oluşturma, personel motivasyonu, tükenmişliği ele alma ve belirsizliği azaltma konularına odaklanılması gerektiği vurgulanmaktadır (Reich, vd., 2020). Örnek olarak koronavirüs sürecinde yaşam kalitesi ve ruh halinin fiziksel aktiviteden olumlu etkilendiği, yaşam kalitesinin egzersizle artacağı ve ruh halinin egzersizle olumlu yönde değişeceğini gösteren araştırma sonuçları da bulunmaktadır (Berk, Öner ve Sarıkaya, 2021).

Araştırma sonunda şu öneriler geliştirilmiştir:

1. Öğretmenlere yönelik sosyal ve psikolojik destek etkinlikleri düzenlenebilir.

2. Öğle araları hobi saatleri oluşturulabilir.

3. Öğrencilerle okul dışı sosyal etkinlikler düzenlenebilir. Örneğin, gerekli önlemlerle gezi düzenlenebilir.

4. Okul bahçesinin ders işlenişinde kullanımı arttırılabilir.

5. Öğretmenlere açık alan drama aktiviteleri hakkında yöntem, teknik vb. eğitim verilebilir.

6. Bütün öğrencilerin uzaktan eğitim gibi süreçlerle ilgili teknolojik donanım ve altyapıya erişim çalışmaları yürütülebilir.

7. Bundan sonraki süreçte öğretmenler çevrimiçi etkinlikleri ne düzeyde ve nasıl kullanabileceği araştırılabilir.

8. Online eğitimin sürdürülebilirliği, öğrenci ve öğretmenlerin hayatboyu öğrenmeye olan katkısı, ne tür eğitimler alınması gerektiği incelenebilir. 


\section{Koronavirüs Salgını Sürecinde Ö̆̆retmen Yaşantıları}

\section{Kaynakça}

Baker, C. N., Peele, H., Daniels, M., Saybe, M., Whalen, K., Overstreet, S., \& The New Orleans, T. I. S. L. C. (2021). The experience of COVID-19 and its impact on teachers' mental Health, coping, and teaching. School Psychology Review, 50(4), 491-504.

Berk, Y., Öner, S. ve Sarıkaya, M. (2021). Covid-19 pandemi sürecinde fiziksel aktivitenin yaşam kalitesi ve duygudurum üzerine etkisinin incelenmesi. ROL Spor Bilimleri Dergisi, 2(2), $52-64$.

Hebebci, M. T., Bertiz, Y., \& Alan, S. (2020). Investigation of views of students and teachers on distance education practices during the Coronavirus (COVID-19) Pandemic. International Journal of Technology in Education and Science (IJTES), 4(4), 267-282.

Herold, B. (2020). The disparities in remote learning under coronavirus (in charts). Education Week, 10.

Joshi, A., Vinay, M., \& Bhaskar, P. (2020). Impact of coronavirus pandemic on the Indian education sector: perspectives of teachers on online teaching and assessments. Interactive Technology and Smart Education, 18(2), 205-226.

Kazu, İ. Y., Bahçeci, F. ve Kurtoğlu Yalçın, C. (2021). Öğretmenlerin koronavirüs pandemisi döneminde verdikleri uzaktan eğitime ilişkin metaforik algıları. Fırat Üniversitesi Sosyal Bilimler Dergisi, 31(2), 701-715.

Konan, N. ve Gür, H. (2021). Covid 19 salgınında fen bilimleri öğretmeni olmak. Taras Shevchenko 6th International Congress On Social Sciences, Kiev, Ukraine.

Konan, N. ve Kıymaz, A. (2021). Koronavirüs (Covid-19) Salgın Döneminde İngilizce Öğretmeni Olmak. International Online Conference on Economics \& Social Sciences, Lahore, Pakistan.

Konan, N. ve Koçer, S. (2021). Koronavirüs (Covid-19) Salgınında Din Kültürü Ve Ahlak Bilgisi Öğretmeni Olmak. Taras Shevchenko 6th International Congress On Social Sciences, Kiev, Ukraine. 
Konan, N. ve Nacar, A. (2021). COVID-19 Pandemisi Sürecinde Bilim ve Sanat Merkezi Öğretmen ve Yöneticilerinin Karşılaştıkları Sorunlar ve Çözüm Önerileri. International Online Conference on Economics \& Social Sciences, Lahore, Pakistan.

Li, Q., Miao, Y., Zeng, X., Tarimo, C. S., Wu, C., \& Wu, J. (2020). Prevalence and factors for anxiety during the coronavirus disease 2019 (COVID-19) epidemic among the teachers in China. Journal of affective disorders, 277, 153-158.

Moçoşoğlu, B. ve Kaya, A. (2020). Koronavirüs hastalığı (COVID-19) sebebiyle uygulanan uzaktan eğitime yönelik öğretmen tutumlarının incelenmesi. Kahramanmaraş Sütçü İmam Üniversitesi Ĕ̈itim Dergisi, 2(1), 15-43.

Onyema, E. M., Eucheria, N. C., Obafemi, F. A., Sen, S., Atonye, F. G., Sharma, A., \& Alsayed, A. O. (2020). Impact of Coronavirus pandemic on education. Journal of Education and Practice, 11(13), 108-121.

Reich, J., Buttimer, C. J., Coleman, D., Colwell, R., Faruqi, F., \& Larke, L. R. (2020, July). What's Lost, What's Left, What's Next: Lessons Learned from The Lived Experiences of Teachers During the Pandemic. Retrieved from https://edarxiv.org/8exp9

Yıldırım, A. ve Şimşek, H. (2011). Sosyal bilimlerde nitel araştırma yöntemleri. Ankara: Seçkin.

Yolcu, H. H. (2020). Koronavirüs (covid-19) pandemi sürecinde sınıf öğretmeni adaylarının uzaktan eğitim deneyimleri. Açıköğretim Uygulamaları ve Araştırmaları Dergisi, 6(4), 237-250. 